\title{
THE ESTABLISHMENT OF THE CELL CULTURE OF PREADIPOCYTES OF COMMON CARP (Cyprinus carpio L.)
}

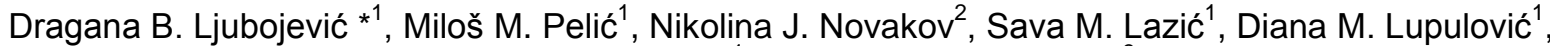 \\ Miroslav A. Ćirković ${ }^{1}$, Marijana Lj. Todorčević ${ }^{3}$ \\ ${ }^{1}$ Scientific Veterinary Institute "Novi Sad"; 21000 Novi Sad, Rumenački put 20, Serbia \\ ${ }^{2}$ University of Novi Sad, Faculty of Agriculture, 21000 Novi Sad, Trg Dositeja Obradovića 8, Serbia \\ ${ }^{3}$ Nofima, Norwegian Institute of Food, Fisheries and Aquaculture Research, Bergin, Norway
}

\author{
${ }^{*}$ Corresponding author: \\ Phone: +381642745389 \\ Fax: +38121518544 \\ E-mail address: dragana@niv.ns.ac.rs
}

\begin{abstract}
Common carp is the most important freshwater fish in aquaculture in Republic of Serbia. Excess fat deposition in the meat and abdominal cavity of farmed carp can affect carp flesh quality, dressing percentage and consequently restrict the further development of aquaculture production. The reasons for lipid deposition in carp flesh and around visceral organs are not well known, and it is important to develop method which would enable us to understand process which occurs in common carp lipid cells. The aim of this study was to establish a new model of common carp preadipocytes and evaluate proliferation and differentiation capacity of carp preadipocytes in vitro. The establishment of the cell culture of preadipocytes of common carp could serve as a valuable tool for studying fat metabolism in this fish species.
\end{abstract}

Key words: common carp, preadipocytes, isolation, cell culture, fat tissue

\section{INTRODUCTION}

Common carp is the most important and the most common freshwater fish in aquaculture in Republic of Serbia. It represents a valuable source of proteins, monounsaturated (Ljubojević et al., 2013 a) and polyunsaturated fatty acids (Ćirković et al., 2012; Ljubojević et al., 2013 b) in human nutrition. Excess fat deposition in the meat and abdominal cavity of farmed carp has increased in the last two decades as a result of the intensification of pond aquaculture and also as a result of improper rearing management and excessive amount of corn in carp nutrition (Ljubojević et al., 2013 c; Trbović et al, 2013). Increased percentage of lipids stored in the edible muscle can affect carp flesh quality
(Ur-banek et al., 2010; Zajic et al., 2013). Moreover, accumulation of fat in carp flesh leads to decreasing dressing percentage (Ljubojević et al., 2012), and creating prejudice that carp is fatty fish and consequently restrict the further development of aquaculture production. However, it is not yet clear how to overcome the surplus fat content in carp meat.

The reasons for lipid deposition in carp flesh and around visceral organs are not well known, and it is important to develop method which would enable us to understand process which occurs in common carp lipid cells. Furthermore, it is of major importance to develop methods to prevent excessive fat deposition in reared common 
carp in order to strengthen the sustainability of the aquaculture industry. Green and Meuth (1974) and Green and Kehinde (1975) were introduced the first immortal line of preadipocytes. Such cell lines have provided valuable information in the field of adipocyte biology and many biological experiments have been performed with immortalized cell lines, since these are commercially available and can be expanded without limitation. These cell lines present a homogenous cell population and can be carried in culture indefinitely. However, such cell lines may differ from cells in vivo in many important viewpoints. Cells that are cultured directly from animal tissue are known as primary cells. Fully differentiated primary cells can be kept in culture for a short time, while unspecialized primary stem cells can be kept in culture for longer periods. However, the function and development of primary cells in culture offers a more relevant model for the in vivo situation than immortalized cell lines, but working with primary cells in culture presents numerous challenges, including the requirement for unique cell supplements and growth conditions.

According to our knowledge, there are no data related to the culture of cells isolated from adipose tissue of common carp. The aim of this study was to establish a new model of common carp preadipocite and evaluate proliferation and differentiation capacity of carp preadipocytes in vitro. The establishment of the cell culture of preadipocytes of common carp could serve as a valuable tool for studying fat metabolism in common carp.

\section{MATERIAL AND METHODS}

Five specimens of two-year-old marketable common carp, average weight 2500 $\mathrm{g}$ were obtained from the largest Serbian fishpond „Ečka“, with semi-intensive production system. The carp were reared on natural food and supplementary diet of extruded feed.

Leibovitz-15 (L-15) with L-glutamine, 4-(2hydroxyethyl)-1-piperazineethanesulfonic acid (HEPES), Penicillin -Streptomycin Solution (Penstrep), Amphotericin B Solution, Gelatin from porcine skin cell, trypsin and Fetal bovine serum (FBS) were all supplied from Sigma Aldrich (St. Louis, MO, USA).

Insulin (recombinant human $Z$ ), triiodothyronine (T3), dexamethasone, isobutylmethylxanthine (IBMX), troglitazone, transferrine, linoleic (LA) and oleic acid (OA), and nylon filters 250/100 were a generous gift from Dr. Marijana Todorčević.

The growth medium was prepared and it contained $87 \%$ L-15; $1 \%$ HEPES; $1 \%$ amphotericin B; $1 \%$ Penstrep and 10\% FBS.

Differentiation-inducing medium (DM) was prepared and contained growth medium supplemented with $20 \mu \mathrm{g} / \mathrm{ml}$ insulin; $10 \mathrm{nM}$ T3; transferrine; $1 \mu \mathrm{M}$ dexametasone; 25 $\mu \mathrm{M}$ IBMX; troglitazone; LA and OA.

Common carp preadipocytes were isolated as described by Vegusdal et al. (2003) and Todorčević et al. (2008) for Atlantic salmon with small changes. Five live carp marketable size were carried from fish pond Ečka to laboratory of Scientific Veterinary Institute "Novi Sad“. The arch bows of the gill were cut. After that, the carp were bled for a couple minutes, and then killed by a blow to the head. The abdomen was carefully cleaned with a cotton swab and alcohol to remove mucus and other impurities, and then the fish were carefully eviscerated. Visceral adipose tissue was carefully cut out, avoiding cross-contamination with the intestinal contents, and then weighted. From one of the carp was not possible to get adipose tissue, most likely due to the time of year (spring). The fat depots were probably depleted during the winter. A total amount of obtained adipose tissue was $22 \mathrm{~g}$. All further operations were performed inside a vertical laminar air flow cabinet. The dissected adipose tissue was washed with L15 , to carefully remove visible blood and transferred into tubes $(50 \mathrm{~mL})$ with $\mathrm{L}-15$ and centrifuged at $1250 \mathrm{rpm}$ for 5 minutes and after that transferred into clean tubes with $\mathrm{L}-15$, then minced, and digested in $0.2 \%$ trypsin solution at room temperature for $1 \mathrm{~h}$ under manually shaking. In order to remove large particle of tissue, blood cells and to obtain a homogenous culture of preadipocytes, the digested tissue suspension was subsequently filtered through 250 and $100 \mu \mathrm{m}$ nylon filters and washed with 
$\mathrm{L}-15$. The obtained cell suspension was centrifuged at $2000 \mathrm{rpm}$ for 10 minutes. Preadipocytes were pelleted at the bottom of tube and the buoyant fat layer with mature adipocytes and the digestion medium were removed carefully by aspiration. After washing twice, the obtained pelleted cells were resuspended in growth medium and seeded onto four cell culture flasks. The cells were kept at $23{ }^{\circ} \mathrm{C}$, a temperature close to the average water temperature which is the optimum for growth of common carp. The growth medium was changed every other day.

Cells in culture were observed with a Zeiss light microscope and digital images were captured daily. Morphology of the cells was observed in primary culture over a period of 12 days. After ten days in culture, preadipocytes reach confluence.

One part of confluent preadipocytes was differentiated in an initial differentiationinducing medium. The other part was split. The culture of preadipocytes was split by dispersing the cells with $2 \mathrm{~mL}$ trypsin for 10 minutes at $23{ }^{\circ} \mathrm{C}$. After addition of GM, subcultures were divided into two flasks.

\section{RESULTS AND DISCUSSION}

After seeding, the isolated preadipocytes of common carp were small with a cytoplasm devoid of lipid droplets and morphologically very similar to fibroblasts, they started to attach and growth the first day (Figure 1).

Mass attaching and growth of the cells were observed on the third day (Figure 2). Then, the cells proliferated exponentially and resembled fibroblasts.

A large increase in the number of cells was observed between days 6 (Figure 3) and 10 , and the cells arrived at a confluence by the tenth day (Figure 4).

At confluence, the growth medium was replaced by a differentiation-inducing medium in two culture flasks. The cells responded rapidly, becoming more rounded in shape, and many lipid droplets of different sizes appeared in the cytoplasm already after two days which is probably a consequence of the regulation of contractile proteins as described by Todorčević et al. (2008). The other part of confluent preadipocytes was split and it was observed that cells started to attach and growth in monolayer.

The adipose tissue of fish is composed of adipocytes with a large variation of diameters as established for common carp (Fauconneau et al., 1995); Atlantic salmon (Zhou et al., 1996) and rainbow trout (Albalat et al., 2005). The presence of adipocytes of different sizes shows that growth in adipose tissue is the result of both hypertrophy (increase in cell size) and hyperplasia (increase in cell number) (Weil et al., 2013). The degree of fat deposition is characterized by the volume and the number of adipocytes, which is regulated by the adipocyte life cycle ( $\mathrm{Ra}$ yalam et al., 2008) which involves both the growth of the fat cells and the formation of mature adipocyte from precursor cells.

In the present research, it was shown that cells started to attach and growth the first day after isolation and this finding is in agreement with the observations of Vegusdal et al. (2003) and Todorčević et al. (2008) for preadipocytes of Atlantic salmon (Salmo salar). On the other hand, Li (2012) observed that cells of grass carp (Ctenopharyngodon idella) started to attach and growth on the day third. Based on these data, it can be said that the time of attachment of preadipocytes varies between the different fish species.

In this study, carp cells were maintained at $23{ }^{\circ} \mathrm{C}$, while grass carp preadipocytes were incubated at $28{ }^{\circ} \mathrm{C}$ ( $\left.\mathrm{Li}, 2012\right)$ and Atlantic salmon preadipocytes were maintained at $13^{\circ} \mathrm{C}$ (Vegusdal et al., 2003; Todorčević et al., 2008). The differences of culture temperature between the preadipocytes of different fish species are related to the environment that the fish live in. It is known that common cap and grass carp live in warm water, while Atlantic salmon lives in cold water.

In this trial, preadipocytes of common carp reach confluence after ten days in culture, which is in agreement with observation of Li (2012). On the other hand, Todorčević et al. (2008) reported that the preadipocytes of Atlantic salmon reach confluence after seven days in culture, which leads to the conclusion that there are differences between different species of fish in mole- 


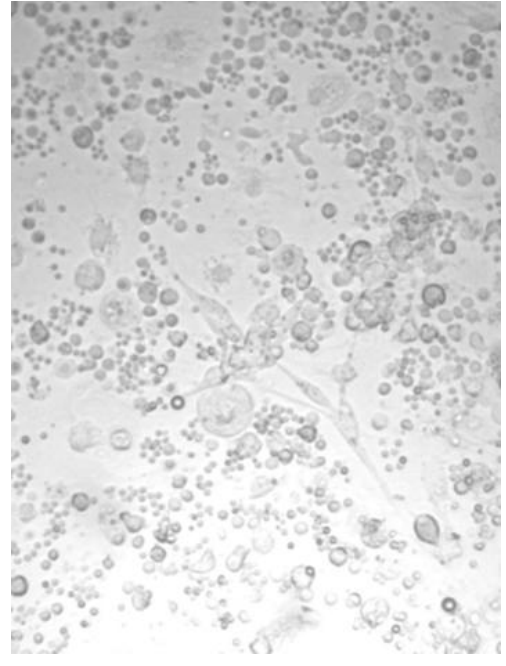

Figure 1. Preadipocytes isolated after seeding of common carp

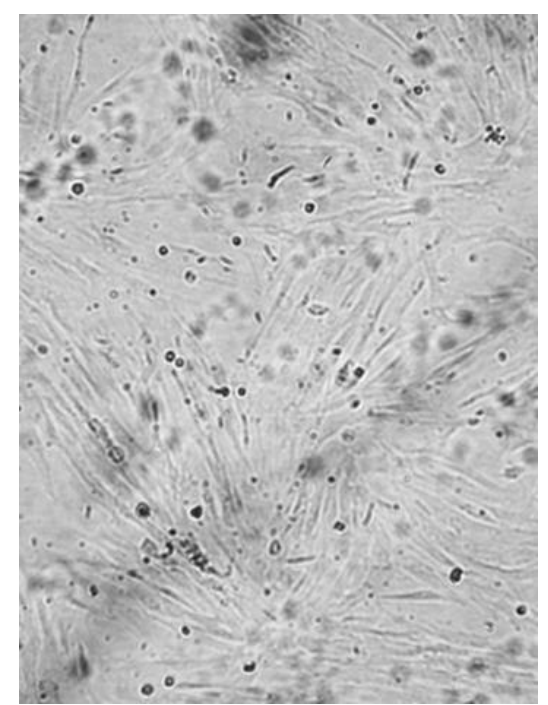

Figure 3. A large increase in the number of labelled preadipocytes on day 6

cular mechanisms governing adipocyte differentiation and physiology. Based on the above mentioned facts, it can be observed that there are differences in morphology and growth of preadipocytes between different species of fish, and the data obtained for one species may not always be appropriate and cannot be applied to other fish species. This indicates the importance of establishing primary cultures of common carp preadipocytes, especially when we take into account that this species is economically the most important in our country and also is one of the most common species worldwide.

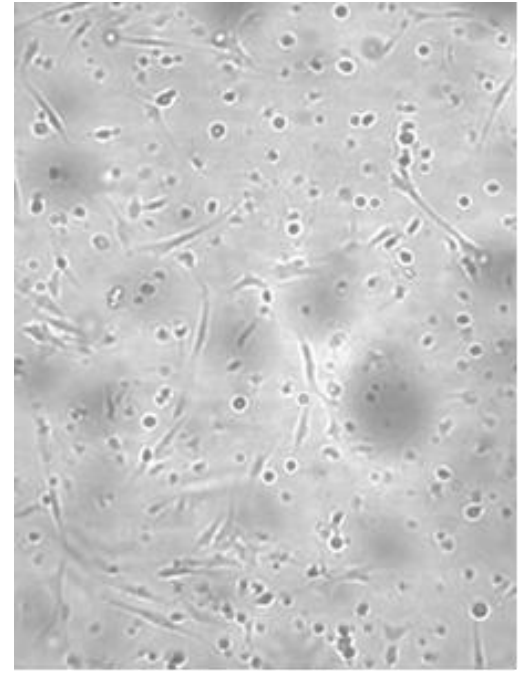

Figure 2. Mass attach and growth of the common carp labelled preadipocytes

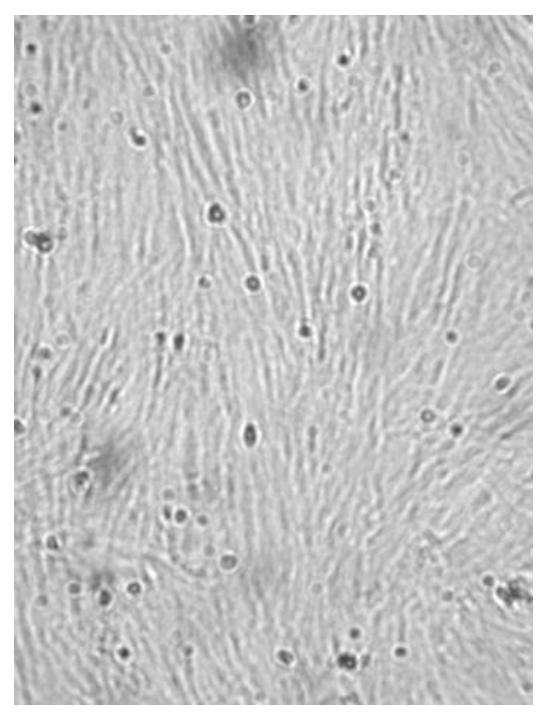

Figure 4. Common carp labelled preadipocytes at confluent stage

This is the first described establishing a primary cell culture of common carp preadipocytes, which represents a major contribution to modern aquaculture.

Todorčević et al. (2010) showed that high dietary levels of $n-3$ highly unsaturated fatty acids (HUFAs) reduce the fat levels in the visceral adipose tissue of Atlantic salmon in comparison to fish fed vegetable oil diets and this findings were in agreement with the in vitro observations (Todorčević et al., 2008) which showed that oleic acid leads to higher lipid accumulation in Atlantic salmon adipocytes in culture than eicosapentaenoic (EPA) and docosahexa- 
enoic (DHA) fatty acids. Also, mitochondrial fatty acid $\beta$-oxidation activity was higher in the fish oil group than it was in the rapeseed oil group. The above mentioned results indicate the importance of in vitro cell cultures of preadipocytes in investtigations of the effects of different nutrients on biochemical processes in the body of fish. It has been shown that the use of an in vitro system has a great potential as the method for testing feed products and understanding cellular and molecular events in fish body.

\section{CONCLUSIONS}

The present results indicate that the convenient and efficient in vitro system is established and it will be important for future studies of biochemical and mole-cular processes that occur during adipogenesis in common carp. An improved understanding of cellular and molecular events occurring during development of fat tissue in carps will enable us to better characterize and define particular requirements, customize feed components, and thus enable development of sustainable feeds, minimize the occurrence of nutritional disorders. Cell cultures provide means to study single-factor effects and the combinations thereof in detail, and further, to investigate the role of particular nutrients and their specific gene interactions, which are not possible when working at the organism level. In addition, whole organisms are complex and vary individually, depending on age, sex, health status, type of meal, genetics etc., which makes it difficult to accurately simulate nutritional processses. In vitro experiments will offer the opportunity to develop standardized methods to study quality of novel and already used feed products by studying the cellular and molecular effect of different types of food products, ranging from proteins to fatty acids and from fat-soluble vitamins to minerals and trace elements as well as of functional feeds such as probiotics, prebiotics and antioxidants. An improved knowledge of the underlying molecular events that regulate the differentiation process of preadipocytes to adipocytes in common carp (Cyprinus carpio) may open new avenues for the prevention of exces- sive storage of lipids in this important aquaculture species.

\section{ACKNOWLEDGEMENTS}

This paper is a result of the research within the project TR31011 "Uticaj kvaliteta komponenata $u$ ishrani ciprinida na kvalitet mesa, gubitke i ekonomičnost proizvodnje (The influence of the quality of the components of food for cyprinid fish species on the quality of meat, losses and the profitability of production)", financed by the Ministry of Education, Science and Technological Development, Republic of Serbia.

\section{REFERENCES}

1. Albalat, A., Gutierrez J., Navarro I. (2005). Regulation of lipolysis in isolated adipocytes of rainbow trout (Oncorhynchus mykiss): The role of insulin and glucagon, Comparative Biochemistry and Physiology Part A: Molecular \& Integrative Physiology, 142, 347-354.

2. Ćirković, M., Ljubojević, D., Đorđević, V., Novakov, N., Petronijević, R., Matekalo-Sverak, V., Trbović, D. (2012). The Breed Effect on Productivity and Meat Nutrient Compsition of Fish, Kafkas Universitesi Veteriner Fakultesi Dergisi, 18, 775-780.

3. Fauconneau, B., Alami-Durante, H., LarocheMarcel, J., Vallot D. (1995). Growth and meat quality relations in carp, Aquaculture, 129, 265297.

4. Green, H., Meuth M. (1974). Established PreAdipose Cell Line and Its Differentiation in Culture, Cell, 3, 127-133.

5. Green, H., Kehinde O. (1975). Established PreAdipose Cell Line and Its Differentiation in Culture. 2. Factors Affecting Adipose Conversion, Cell, 5, 19-27.

6. Li, Y. (2012). Establishment and evaluation of a new model for studying lipogenesis in grass carp (Ctenopharyngodon idella) preadipocytes, In Vitro Cellular \& Developmental Biology Animal, 48, 37-42.

7. Ljubojević, D., Ćirković, M., Novakov, N., Babić, J., Lujić, J., Marković T. (2012). Faktori koji utiču na randman šaranskih riba, Tehnologija mesa, 53, 14-19.

8. Ljubojević, D., Ćirković, M., Đorđević, V., Puvača, N., Trbović, D., Vukadinov, J., Plavša, N. (2013a). Fat quality of marketable fresh water fish species in the Republic of Serbia, Czech Journal of Food Sciences, 31, 445-450.

9. Ljubojević, D., Trbović, D., Lujić, J., BjelićČabrilo, O., Kostić, D., Novakov, N., Ćirković, M. (2013b). Fatty Acid Composition of Fishes from Inland Waters, Bulgarian Journal of Agricultural Science, 19, 62-71.

10. Ljubojević, D., Ćirković, M., Novakov, N., Jovanović, R., Janković, S., Đorđević, V., Mašić, Z. (2013c). Productivity and Meat Nutrient in Fish: 
The Diet Effect, Kafkas Universitesi Veteriner Fakultesi Dergisi, 19, 43-49.

11. Todorčević, M., Vegusdal, A., Gjoen, T., Sundvold, H., Torstensen, B. E., Kjaer, M. A., Ruyter, B. (2008). Changes in fatty acids metabolism during differentiation of Atlantic salmon preadipocytes; Effects of $n-3$ and n-9 fatty acids, Biochimica et Biophysica Acta, 1781, 326-335.

12. Todorčević, M., Škugor, S., Krasnov, A., Ruyter, B. (2010). Gene expression profiles in Atlantic salmon adipose-derived stromo-vascular fraction during differentiation into adipocytes, BMC Genomics, 11.1, 39.

13. Trbović, D., Marković, Z., Milojković-Opsenica, D., Petronijević, R., Spirić, D., Đjinović-Stojanović, J., Spirić A. (2013). Influence of diet on proximate composition and fatty acid profile in common carp (Cyprinus carpio), Journal of Food Composition and Analysis, 31, 75-81.

14. Urbanek, M., Hartvich, P., Vacha, F., Rost, F.M.
(2010). Investigation of fat content in market common carp (Cyprinus carpio) flesh during the growing season, Aquaculture Nutrition, 16, 511519.

15. Vegusdal, A., Sundvold, H., Gjoen, T., Ruyter, B. (2003). An in vitro method for studying the proliferation and differentiation of Atlantic salmon preadipocytes, Lipids, 38, 289-296.

16. Weil, C., Lefevre, F., Bugeon, J. (2013). Characteristics and metabolism of different adipose tissues in fish, Reviews in Fish Biology and Fisheries, 23, 157-173.

17. Zajic, T., Mraz, J., Sampels, S., Pickova, J. (2013). Fillet quality changes as a result of purging of common carp (Cyprinus carpio L.) with special regard to weight loss and lipid profile, Aquaculture, 400-401, 111-119.

18. Zhou, S.Y., Ackman, R. G., Morrison, C. (1996). Storage of lipids in the myosepta of Atlantic salmon (Salmo salar), Fish Physiology and Biochemistry, 14, 171-178.

\title{
УСПОСТАВЉАЊЕ IN VITRO МЕТОДЕ ЗА ИСТРАЖИВАЊЕ ДИФЕРЕНЦИЈАЦИЈЕ ПРЕАДИПОЦИТА ИЗОЛОВАНИХ ИЗ ВИСЦЕРАЛНОГ АДИПОЗНОГ ТКИВА ШАРАНА (Cyprinus carpio L.)
}

\author{
Драгана Б. Љубојевић夫" ${ }^{*}$ Милош М. Пелић ${ }^{1}$, Николина Ј. Новаков ${ }^{2}$; Сава М. Лазић ${ }^{1}$ \\ Диана М. Лупуловић ${ }^{1}$, Мирослав А. Ћирковић ${ }^{1}$, Маријана Љ. Тодорчевић ${ }^{3}$ \\ 'Научни институт за ветеринарство „Нови Сад“, 21000 Нови Сад, Руменачки пут 20, \\ Србија \\ ${ }^{2}$ Универзитет у Новом Саду, Пољопривредни фракултет, 21000 Нови Сад, \\ Трг Доситеја Обрадовића 8, Србија \\ ${ }^{3}$ Nofima, Norwegian Institute of Food, Fisheries and Aquaculture Research, Бергин, \\ Норвешка
}

Сажетак: Шаран је најважнија слатководна риба у аквакултури Републике Србије. Прекомерно депоновање масти у месу и абдоминалној дупљи гајеног шарана може да утиче на квалитет меса шарана, рандман и последично да представља ограничавајући фактор у развоју рибарске производње. Разлози за прекомерно депоновање масти у месу шарана и око висцералних органа нису довољно проучени и важно је развити методу која ће омогућити разумевање процеса који се одвијају на нивоу масних ћелија шарана. Циљ овог рада је био да се успостави нови модел преадипоцита шарана и да се изучи могућност пролиферације и диференцијације преадипоцита шарана in vitro. Успостављање ћелијске културе преадипоцита шарана има потенцијал у будућим истраживањима метаболизма масти код ове врсте рибе.

Кључне речи: шаран, преадипоцити, изолација, ћелијска култура, масно ткиво

Received: 28 July 2014 